Original article

Section: Food Chemistry Section

\title{
Survival of Wild Strains of Lactobacilli During Kombucha Fermentation and Their Contribution to Functional Characteristics of Beverage
}

\author{
Dragoljub Cvetkovićl, Aleksandra Ranitovic ${ }^{1 *}$, Dragiša Savić, \\ Nataša Jokoviç ${ }^{3}$, Ana Vidaković ${ }^{1}$, Lato Pezo ${ }^{4}$, Siniša Markov ${ }^{1}$ \\ ${ }^{1}$ Department of Biotechnology and Pharmaceutical Engineering, Faculty of Technology Novi Sad, \\ University of Novi Sad, 1 Bulevar cara Lazara, 21000 Novi Sad, Serbia \\ ${ }^{2}$ Department of Biotechnology, Faculty of Technology, University of Niš, 124 Bulevar Oslobođenja, 16000 Leskovac, Serbia \\ ${ }^{3}$ Department of Molecular Biology and Phisiology, Faculty of Science and Mathematics, \\ University of Niš, 33 Višegradska, 18106 Niš, Serbia \\ ${ }^{4}$ Institute of General and Physical Chemistry, University of Belgrade, 12/V Studentski trg, 11000 Belgrade, Serbia
}

Key words: Kombucha, tea fungus, lactobacilli, lactic acid, fermentation

Kombucha is a fermented tea beverage, which is traditionally prepared by fermenting sweetened black tea with tea fungus, which is a consortium of yeasts and acetic acid bacteria. In this paper, viability of selected wild strains of lactobacilli during Kombucha fermentation, their interaction with tea fungus and their contribution in obtaining a beverage of increased functional characteristics were tested. Five wild strains which were isolated from traditionally fermented foods were separately added on the second day of Kombucha fermentation. Count of yeasts, acetic acid bacteria and lactobacilli, as well as pH, titratable acidity, and content of L- and D-lactic acid during Kombucha fermentation were determined. Wild strains of lactobacilli demonstrated a differentiated survivability and the counts in fermentation broth (i.e. Kombucha beverages) depending on the strain applied. The addition of wild Lactobacillus spp. during Kombucha fermentation had no effect on the physiological activity of tea fungus, but they contributed to a significant increase in lactic acid content in the beverage. The highest lactic acid content during Kombucha fermentation was produced by the strain of Lactobacillus plantarum isolated from 40-day-old cream, while the strain of Lactobacillus hilgardii (from sour dough) showed the highest viability.

\section{INTRODUCTION}

Kombucha is a traditional fermented beverage originating from the northeast China (former Manchuria region) and later spread to Russia and the rest of the world. Nowadays, Kombucha has become very popular in the Western world (North America and Europe) and is often claimed to exhibit healthful properties, which include anti-microbial, anti-oxidant, anti-carcinogenic [Jayabalan et al., 2011], anti-diabetic [Hiremath et al., 2002; Aloulou et al., 2012] effects, as well as treatment for gastric ulcers [Banerjee et al., 2010] and high cholesterol [Yang et al., 2009]. It has also been shown to impact the immune response [Ram et al., 2000] and liver detoxification [Lončar et al., 2000].

Kombucha is typically prepared by fermenting sweetened black tea inoculated with tea fungus pellicle or previously fermented broth (i.e. Kombucha) at a level of 100-200 mL/L. The substrate is incubated statically under aerobic conditions at $20-28^{\circ} \mathrm{C}$ [Sievers et al., 1995]. Duration of fermentation could differ, even up to 60 days, and in that case, the obtained

\footnotetext{
* Corresponding Author: +381214853730;

E-mail: sanja@tf.uns.ac.rs (A. Ranitović)
}

beverage has a mild vinegar taste [Chen \& Liu, 2000]. In order to obtain a pleasantly sour, sweetened beverage, fermentation should be terminated when titratable acidity (TA) of fermentation broth reaches 4-4.5 g acetic acid/L, that is confirmed by Kombucha consumers [Cvetković et al., 2008]. The tea fungus is a consortium of acetic acid bacteria (AAB) (Gluconacetobacter xylinum, previously known as Acetobacter xylinum, which is the primary and best studied bacteria in Kombucha) and yeasts (species of the genera Saccharomyces, Torulopsis, Pichia, Brettanomyces, Zygosaccharomyces, Candida and Saccharomycoides) [Yamada et al., 1997; Greenwalt et al., 2000; Teoh et al., 2004; Chu \& Chen, 2006]. It is well known that the microbial community may vary between different Kombucha cultures across the globe depending upon the source of the inoculum used. The role of yeasts in the Kombucha fermentation is to hydrolyze sucrose from cultivation medium to glucose and fructose and metabolize these monosaccharides to ethanol, which is further oxidized to acetic acid by $\mathrm{AAB}$. AAB cannot uptake sucrose alone, because of the lack of enzymes for the extracellular hydrolysis of sucrose or its transport into the cell. Also, AAB use yeast-derived glucose to synthesize gluconic acid and bacterial cellulose in the form of pellicle which is commonly described as the "fungus" 
[Greenwalt et al., 2000; Kurtzman et al., 2001]. Acetic acid, ethanol and gluconic acid are the main tea fungus products [Blanc, 1996]. Other components present in Kombucha are fructose, glucose, ethyl-gluconate, oxalic acid, saccharic acid, keto-gluconic acids, lactic acid as well as tea components (catehins, theaflavins, flavonols etc.), and enzymes (invertase, amylase, other oxidative enzymes etc.) [Reiss, 1994; Greenwalt et al., 2000]. Although the type of sugar (sucrose, lactose, glucose or fructose) may have a distinct influence on the formation of ethanol and lactic acid, the concentration of individual sugars has no pronounced effect [Reiss, 1994]. When lactose was used as a carbon source, the final products of fermentation were acetic and lactic acid as well as ethanol [BellosoMorales \& Hernández-Sánchez, 2003]. Lactic acid appears in Kombucha in its most potent L-form [Malbaša et al., 2002]. L-Lactic acid is the biologically important isomer that assists circulation of the blood and prevents decay in the bowels and constipation. Also, it maintains the balance between acids and alkalines, as well as stimulates secretion of stomach enzymes and detoxification process [Kaufman, 1995].

It is well known that lactic acid is the major product during sugar fermentation in lactic acid bacteria (LAB), but these bacteria were not detected in the Kombucha according to Sievers et al. [1995]. Generally, there are insufficient data about the presence of LAB in Kombucha, i.e. tea fungus culture and their number during fermentation of sweetened tea. One of the reasons is that the majority of microbiological analyses of tea fungus have been based on culture techniques [Chakravorty et al., 2016]. Recently, Marsh et al. [2014] have performed sequence-based analysis of the bacterial and yeast populations of Kombucha. They were identified Lactobacillus spp. as prominent population (up to $30 \%$ ), with a number of sub-dominant genera. According to Marsh et al. [2014], lactobacilli have been isolated in only two previous Kombucha studies, both of which focused on Chinese Kombuchas. Velićanski [2012] did not detect LAB (streptococci, lactobacilli and bifidobacteria) in tea fungus which was used in her study as a starter culture. In the absence of LAB, the lactic acid during tea fungus cultivation was formed by AAB from ethanol and acetic acid [Reiss, 1994]. Yeasts lack the lactate dehydrogenase enzyme, and are unable to process during glycolysis and produce lactic acid from pyruvate [Gao et al., 2009].

Previous results of Velićanski [2012] also have shown very low viability of starter commercial LAB cultures during Kombucha fermentation. Taking into account beneficial health effects of LAB (especially as probiotics), as well as the absence of literature data, the author tested the possibility to produce a Kombucha with improved functional (probiotic) characteristics using commercial cultures of LAB. Probiotic foods which contain viable cells (least $10^{6} \mathrm{cfu} / \mathrm{mL}$ ) of probiotic cultures such as lactobacilli and bifidobaterium provide several health benefits, as they help in maintaining a good balance and composition of the intestinal microbiota, and increase the resistance against invasion of pathogens [Tripathi \& Giri, 2014].

The aim of this study was therefore to test viability of selected wild strains of lactobacilli during Kombucha fermentation, their interaction with tea fungus and their contribution in obtaining a beverage of increased functional characteristics compared with the traditional one.

\section{MATERIALS AND METHODS}

\section{Tea fungus}

Fermentation was performed by using the local tea fungus culture, for which previous studies showed that it contained at least five yeast strains (Saccharomycodes ludwigii, Saccharomyces cerevisiae, Saccharomyces bisporus, Torulopsis spp., and Zygosaccharomyces spp.) and two bacterial strains of the Acetobacter genera [Markov et al., 2001; Velićanski, 2012].

\section{Tea fungus cultivation}

The substrate for tea fungus cultivation was prepared by adding $70 \mathrm{~g}$ of sucrose into $1 \mathrm{~L}$ of tap water. The medium was boiled and $3 \mathrm{~g} / \mathrm{L}$ of black tea ("Fructus", Bačka Palanka, Republic of Serbia) was added. After 15 min, tea leaves were removed by filtration. After cooling it to the room temperature, the tea was inoculated with $100 \mathrm{~mL} / \mathrm{L}$ of the fermentation broth from the previous fermentation obtained under the same conditions. Sterile glass jars (volume $0.72 \mathrm{~L}$, diameter $8 \mathrm{~cm}$ ) were filled in with $0.33 \mathrm{~L}$ of inocula. The glass jars were covered with a cheesecloth, and the fermentation at $28 \pm 0.2^{\circ} \mathrm{C}$ was monitored to obtain a beverage of optimal acidity $(\mathrm{TA}=4-4.5 \mathrm{~g} / \mathrm{L})$. All fermentations were performed in triplicate.

\section{Preparation of lactobacilli suspensions for inoculation}

Suspensions of lactobacilli for inoculation were added into the fermentation broth two days after the beginning of fermentation. Wild Lactobacillus strains (Lb-1-Lb-5) included in this study were isolated from traditional fermented food from the territory of the Republic of Serbia (Table 1). Identification of strains was performed by the molecular identification by using (GTG) $)_{5}$-PCR and sequence analysis of $16 \mathrm{~S}$ rRNA gene. Strains were stored at $-80^{\circ} \mathrm{C}$ in Lactobacillus MRS Agar (Himedia, Mumbai, India), supplemented with $200 \mathrm{~g} / \mathrm{L}$ of glycerol in the Laboratory of Microbiology, Faculty of Technology, University of Novi Sad, Serbia. Wild Lactobacillus strains from the stock were subcultured twice in MRS broth (Himedia, Mumbai, India) at $28^{\circ} \mathrm{C}$ for $24 \mathrm{~h}$. Subcultured wild strains were centrifuged at $2504 \times g$ (LC-320 centrifuge, Tehtnica, Železniki, Slovenia) for $15 \mathrm{~min}$. The sediment was resuspended twice in $8.5 \mathrm{~g} / \mathrm{L} \mathrm{NaCl}$ and centrifuged under the same conditions.

Each suspension was separately added into glass jar after $48 \mathrm{~h}$ from the start of Kombucha fermentation in the quantity

TABLE 1. Wild Lactobacillus strains applied in Kombucha fermentation.

\begin{tabular}{|c|c|c|c|}
\hline $\begin{array}{l}\text { Strain } \\
\text { designation }\end{array}$ & $\begin{array}{c}\text { Name } \\
\text { of the strain }\end{array}$ & $\begin{array}{c}\text { Origin } \\
\text { of the strain }\end{array}$ & $\begin{array}{c}\text { Type of sugar } \\
\text { metabolism }\end{array}$ \\
\hline Lb-1 & L. hilgardii & sour dough & heterofermentative \\
\hline $\mathrm{Lb}-2$ & L. fermentum & $\begin{array}{l}\text { 1-month old } \\
\text { cheese }\end{array}$ & heterofermentative \\
\hline $\mathrm{Lb}-3$ & L. plantarum & $\begin{array}{l}\text { 2-month old } \\
\text { cheese }\end{array}$ & homofermentative \\
\hline $\mathrm{Lb}-4$ & L. plantarum & $\begin{array}{l}\text { 40-day old } \\
\text { cream }\end{array}$ & homofermentative \\
\hline Lb-5 & L. plantarum & $\begin{array}{l}\text { 7-month } \\
\text { old cream }\end{array}$ & homofermentative \\
\hline
\end{tabular}


of $10 \%(\mathrm{v} / \mathrm{v})$. The expected number of lactobacilli at the start point of fermentations was not lower than $10^{7} \mathrm{cfu} / \mathrm{mL}$, while the exact number was determined by the pour plate method one hour after inoculation and during the following two days.

\section{Sampling}

Sampling of fermentation broth during tea fungus cultivation was performed periodically for further analysis. Each glass jar was sampled only once in order to avoid a potential contamination. From each jar, $1 \mathrm{~mL}$ of fermentation broth was taken under sterile conditions for the microbiological analysis and $20 \mathrm{~mL}$ for measuring the $\mathrm{pH}$ value and TA. The control sample (Control Kombucha) was sweetened black tea which was not inoculated with lactobacilli. After four days of fermentation, samples of Kombucha inoculated with Lactobacillus strains were bottled and stored at $+4^{\circ} \mathrm{C}$ for testing bacteria viability during storage. During 10-day storage, samples were taken to determine $\mathrm{pH}$, TA and number of lactobacilli.

\section{Methods of analysis}

The $\mathrm{pH}$ values were measured by using an electronic pH meter (HI 9321, HANNA Instruments, Limena, Italy) calibrated at $\mathrm{pH} 4.0$ and 7.0. The TA was determined according to Jacobson [2006]. After removing $\mathrm{CO}_{2}$ from the fermentation broth, a $20-\mathrm{mL}$ aliquot was taken and titrated with $0.1 \mathrm{~mol} / \mathrm{L}$ of $\mathrm{NaOH}$. The TA was expressed in grams of acetic acid per liter of the sample. D-lactic acid and L-lactic acid content was determined by using D-/L-lactic acid kit (Megazyme, Co. Wicklow, Ireland, K-DLATE 06/08). Number of yeasts, AAB, lactococci, lactobacilli, and bifidobacteria in the fermentation broth was determined by the plate counting method. The medium for enumeration of yeasts was Sabouraud-4\% Maltose Agar (Merck, Darmstadt, Germany) with the addition of $50 \mathrm{mg} / \mathrm{L}$ of chloramfenicol (Sigma-Aldrich, St. Louis, USA); plates were incubated at $28^{\circ} \mathrm{C}$ for $72 \mathrm{~h}$. The medium for the determination of the number of AAB was Yeast Peptone Mannitol Agar (Difco, Detroit, USA), containing $500 \mathrm{mg} / \mathrm{L}$ of cycloheximide (Sigma-Aldrich, St. Louis, USA). The incubation at $28^{\circ} \mathrm{C}$ took 5-7 days. Number of lactobacilli was determined using Lactobacillus MRS Agar (Himedia, Mumbai, India) by adding $500 \mathrm{mg} / \mathrm{L}$ of cycloheximide. Streptococci was determined by using M17 Agar Base (Himedia, Mumbai, India) under aerobic conditions at $28^{\circ} \mathrm{C}$ for $72 \mathrm{~h}$. Number of bifidobacteria were determined by using Wilkins Chalgren Anaerobic Agar Base (Himedia, Mumbai, India) and TOS MUP Medium (Merck, Darmstadt, Germany). The incubation was performed under anaerobic conditions by using Anaerocult $\mathrm{A}^{\circledR}$ (Merck, Darmstadt, Germany) at $28^{\circ} \mathrm{C}$ for $72 \mathrm{~h}$.

\section{Statistical analysis}

All experiments were performed in triplicate, under the same conditions, while each quantity was measured three times. The obtained values used for further processing are the averages of all the measurements presented as a mean \pm standard deviation. Analysis of variance (ANOVA) and Tukey's HSD test for comparison of sample means were used to analyze variations in the observed parameters among the samples. The data were processed statistically using the software package STATISTICA 10.0 (StatSoft Inc., Tulsa, OK, USA).

\section{RESULTS AND DISCUSSION}

\section{Chemical and microbial changes during Kombucha fermentations}

Results of determination of lactobacilli, streptococci, and bifidobacteria (LAB) numbers in the fermentation broth prior to inoculation and during fermentation of Control Kombucha showed absence of these bacteria (Table 2). Wild strains of lactobacilli Lb-1-Lb-5 (Table 1) were separately added the second day of tea fungus cultivation after chemical $(\mathrm{pH}$ and TA) and microbiological (number of yeasts and $\mathrm{AAB}$ ) analysis of the fermentation broth. One of the reasons why lactobacilli were not added at the beginning of cultivation was to avoid the osmotic stress, which cells would be exposed to due to a high concentration of sucrose $(70 \mathrm{~g} / \mathrm{L})$ as the only carbon source in the cultivation medium [Panesar et al., 2007]. The other reason is a more favorable profile of sugar as a carbon source for lactobacilli in the cultivation medium after two days of fermentation. Namely, the previous results have shown that after two days of cultivation of tea fungus, the greatest portion of sucrose in the broth was hydrolyzed and that quantities of glucose and fructose in the fermentation broth were less than $20 \mathrm{~g} / \mathrm{L}$ [Cvetković et al., 2008]. Such conditions in the cultivation broth are much more favorable for lactobacilli, both in terms of concentration and type of the carbon source, bearing in mind that LAB easily uptake glucose and fructose [Nauth, 2006]. In addition to the nutrient type and concentration, LAB viability and fermentation ability are also affected by cultivation temperature and $\mathrm{pH}$ of the environment. Temperature for tea fungus cultivation of $28^{\circ} \mathrm{C}$ is not a limiting factor for growth of LAB and proliferation as, according to the data, the optimal temperature for growth of $\mathrm{LAB}$ varies across genera from 20 to $45^{\circ} \mathrm{C}$ [Kandler \& Weiss, 1984]. Depending on the optimal temperatures, most LAB come under the mesophilic category [Panesar et al., 2007]. A pH of a fermentation broth has a more significant impact on the survival and physiological activity of LAB in the course of Kombucha fermentation. According to the data of Panesar et al. [2007], an optimal pH range for rapid and complete carbohydrate fermentation by LAB is 5.5-6.0. Fermentation is strongly inhibited at a lower $\mathrm{pH}$ and ceases at $\mathrm{pH}$ values below 4.5. As a matter of fact, a significant reduction in the number of commercial cultures (Lactobacillus acidophilus LAFTI ${ }^{\circledR}$ L10, Lactobacillus delbrueckii ssp. bulgaricus and Lactobacillus casei LAFTI ${ }^{\circledR}$ L26 (DSM Food Specialties, Australia)) used in the previous study of Velićanski [2012], can be explained by unfavorable values of environment $\mathrm{pH}$. Also, these cultures of lactobacilli were intended for milk fermentation and their selection was made on the basis of conditions existing during milk fermentation, which are different from those during Kombucha fermentation. According to the results presented in Table 2, statistically significant differences $(p<0.05)$ between the means in the number of lactobacilli were observed for most of the samples after the inoculation (the second fermentation day). Significant differences were also noticed in most of the samples between means in the content of D-lactic acid and L-lactic acid .

The $\mathrm{pH}$ value of the sweetened black tea before inoculation was 6.94 and it declined to 4.29-4.52 after the inoculation with 
TABLE 2. Number of lactobacilli (log cfu/mL) and content of lactic acids $(\mathrm{mg} / \mathrm{L})$ in Control Kombucha and Kombucha inoculated with wild strains of lactobacilli (Kombucha+Lb-1 - Kombucha+Lb-5).

\begin{tabular}{|c|c|c|c|c|}
\hline Sample & Fermentation time (days) & Number of lactobacilli & D-Lactic acid & L-Lactic acid \\
\hline \multirow{5}{*}{$\begin{array}{l}\text { Control } \\
\text { Kombucha* }\end{array}$} & 0 & $<1$ & $0.3 \pm 0.1^{p}$ & $3.3 \pm 0.5^{\mathrm{s}}$ \\
\hline & 1 & $<1$ & $1.7 \pm 0.1^{\mathrm{n}}$ & $12.5 \pm 0.1^{\mathrm{j}}$ \\
\hline & 2 & $<1$ & $3.8 \pm 0.6$ & $10.2 \pm 0.8^{\mathrm{m}}$ \\
\hline & 3 & $<1$ & $4.2 \pm 0.1^{\mathrm{k}}$ & $12.9 \pm 0.9^{j}$ \\
\hline & 4 & $<1$ & $7.7 \pm 0.1^{\mathrm{j}}$ & $38.4 \pm 0.1^{\mathrm{g}}$ \\
\hline \multirow{5}{*}{$\begin{array}{l}\text { Kombucha } \\
+ \text { Lb-1 }\end{array}$} & 0 & $<1$ & $0.3 \pm 0.1^{p}$ & $3.0 \pm 0.6^{\mathrm{su}}$ \\
\hline & 1 & $<1$ & $1.8 \pm 0.1^{\mathrm{m}}$ & $13.0 \pm 0.2^{\mathrm{j}}$ \\
\hline & 2 & $8.16 \pm 0.15^{\mathrm{a}}$ & $3.7 \pm 0.9^{1}$ & $9.8 \pm 0.3^{\mathrm{m}}$ \\
\hline & 3 & $7.76 \pm 0.10^{\mathrm{b}}$ & $150.7 \pm 1.5^{\mathrm{d}}$ & $44.9 \pm 0.1^{\mathrm{e}}$ \\
\hline & 4 & $7.60 \pm 0.04^{c}$ & $189.1 \pm 4.2^{\mathrm{c}}$ & $51.9 \pm 0.1^{\mathrm{d}}$ \\
\hline \multirow{5}{*}{$\begin{array}{l}\text { Kombucha } \\
+ \text { Lb-2 }\end{array}$} & 0 & $<1$ & $0.5 \pm 0.1^{\circ}$ & $3.8 \pm 0.4^{r}$ \\
\hline & 1 & $<1$ & $1.9 \pm 0.1^{\mathrm{m}}$ & $14.5 \pm 0.3^{\mathrm{i}}$ \\
\hline & 2 & $7.18 \pm 0.01^{\mathrm{f}}$ & $3.9 \pm 0.1^{1}$ & $6.6 \pm 0.1^{\mathrm{p}}$ \\
\hline & 3 & $6.10 \pm 0.11^{\mathrm{h}}$ & $43.2 \pm 1.4^{\mathrm{g}}$ & $31.4 \pm 0.1^{\mathrm{h}}$ \\
\hline & 4 & $<1$ & $58.2 \pm 0.7^{\mathrm{f}}$ & $37.6 \pm 0.4^{g}$ \\
\hline \multirow{5}{*}{$\begin{array}{l}\text { Kombucha } \\
+ \text { Lb-3 }\end{array}$} & 0 & $<1$ & $0.5 \pm 0.1^{\circ}$ & $3.8 \pm 0.5^{\mathrm{r}}$ \\
\hline & 1 & $<1$ & $1.9 \pm 0.5^{\mathrm{m}}$ & $11.5 \pm 0.1^{\mathrm{k}}$ \\
\hline & 2 & $7.38 \pm 0.03^{\mathrm{e}}$ & $3.5 \pm 0.0^{1}$ & $7.0 \pm 0.1^{\circ}$ \\
\hline & 3 & $2.02 \pm 0.09^{1}$ & $14.4 \pm 0.1^{\mathrm{h}}$ & $30.0 \pm 1.1^{\mathrm{h}}$ \\
\hline & 4 & $<1$ & $11.1 \pm 0.3^{\mathrm{i}}$ & $53.6 \pm 0.5^{\mathrm{c}}$ \\
\hline \multirow{5}{*}{$\begin{array}{l}\text { Kombucha } \\
+ \text { Lb-4 }\end{array}$} & 0 & $<1$ & $0.3 \pm 0.1^{\mathrm{p}}$ & $3.3 \pm 0.5^{\mathrm{s}}$ \\
\hline & 1 & $<1$ & $2.1 \pm 0.3^{\mathrm{m}}$ & $10.5 \pm 0.3^{1}$ \\
\hline & 2 & $7.54 \pm 0.02^{\mathrm{d}}$ & $3.8 \pm 0.2^{1}$ & $8.5 \pm 0.2^{\mathrm{n}}$ \\
\hline & 3 & $3.61 \pm 0.41^{\mathrm{i}}$ & $203.7 \pm 1.4^{b}$ & $71.0 \pm 1.0^{\mathrm{b}}$ \\
\hline & 4 & $2.95 \pm 0.12^{\mathrm{j}}$ & $247.6 \pm 0.5^{\mathrm{a}}$ & $95.5 \pm 0.5^{\mathrm{a}}$ \\
\hline \multirow{5}{*}{$\begin{array}{l}\text { Kombucha } \\
+ \text { Lb-5 }\end{array}$} & 0 & $<1$ & $0.6 \pm 0.2^{\circ}$ & $3.0 \pm 0.3^{u}$ \\
\hline & 1 & $<1$ & $1.7 \pm 0.1^{\mathrm{n}}$ & $12.5 \pm 0.1^{\mathrm{j}}$ \\
\hline & 2 & $7.13 \pm 0.02^{\mathrm{g}}$ & $3.3 \pm 0.1^{1}$ & $5.1 \pm 0.5^{q}$ \\
\hline & 3 & $2.47 \pm 0.32^{\mathrm{k}}$ & $94.6 \pm 0.5^{\mathrm{e}}$ & $37.8 \pm 0.3^{g}$ \\
\hline & 4 & $1.90 \pm 0.01^{\mathrm{m}}$ & $95.0 \pm 0.2^{\mathrm{e}}$ & $40.5 \pm 0.5^{\mathrm{f}}$ \\
\hline
\end{tabular}

*The obtained results for Control Kombucha refer also to the number of bifidobacteria and streptococci. Different letters in superscript in columns indicate a significant difference at $p<0.05$ according to Tukey's HSD test. Lb-1-Lb-5: see Table 1.

the fermentation broth from the previous cultivation (Table 3). After two days of fermentation, the $\mathrm{pH}$ decreased by about 1 unit and in the next two days the decrease was only by $0.3-$ -0.4 units. At the end of the process, the $\mathrm{pH}$ of fermentation broths reached values of 3.03-3.16. Changes in the $\mathrm{pH}$ during tea fungus cultivation were similar for both, Control Kombucha as well as medium inoculated with Lactobacillus strains. The TA (Table 3) increased constantly from the beginning till the end of the fermentation for all samples. TA of cultivation medium after inoculation was around $0.3 \mathrm{~g} / \mathrm{L}$ and after two days of fermentation, it reached 1.62-2.16 g/L. In the following two days, some differences were noted between the acidity of samples. The highest TA at the end of fermentations was determined for Kombucha with strain Lb-3 (7.01 g/L), which was higher by $0.78-1.55 \mathrm{~g} / \mathrm{L}$ compared with the other beverages. The TA of the Control Kombucha after four days of fermentation was $6.23 \mathrm{~g} / \mathrm{L}$. During Kombucha fermentations, the value of $\mathrm{pH}$ decreased significantly $(p<0.05)$ in the first 
TABLE 3. The change of $\mathrm{pH}$, titratable acidity (TA) $(\mathrm{g} / \mathrm{L})$, and numbers of acetic acid bacteria and yeasts (log cfu/mL) during Kombucha fermentations.

\begin{tabular}{|c|c|c|c|c|c|}
\hline Sample & $\begin{array}{c}\text { Fermentation time } \\
\text { (days) }\end{array}$ & $\mathrm{pH}$ & $\mathrm{TA}$ & $\begin{array}{c}\text { Number of acetic } \\
\text { acid bacteria }\end{array}$ & Number of yeasts \\
\hline \multirow{5}{*}{ Control } & 0 & $4.43 \pm 0.00^{\mathrm{b}}$ & $0.28 \pm 0.00^{r}$ & $4.30 \pm 0.10^{\mathrm{g}}$ & $5.78 \pm 0.03^{c}$ \\
\hline & 1 & $4.19 \pm 0.06^{\mathrm{d}}$ & $0.51 \pm 0.03^{\circ}$ & $5.58 \pm 0.12^{\mathrm{cd}}$ & $6.71 \pm 0.09^{a b}$ \\
\hline & 2 & $3.57 \pm 0.02^{\mathrm{f}}$ & $1.62 \pm 0.05^{1}$ & $6.12 \pm 0.02^{b}$ & $6.87 \pm 0.04^{\mathrm{a}}$ \\
\hline & 3 & $3.21 \pm 0.03^{\mathrm{kl}}$ & $4.32 \pm 0.05^{\mathrm{e}}$ & $6.34 \pm 0.14^{\mathrm{a}}$ & $6.87 \pm 0.01^{\mathrm{a}}$ \\
\hline & 4 & $3.05 \pm 0.01^{\mathrm{m}}$ & $6.23 \pm 0.07^{b}$ & $5.46 \pm 0.11^{\mathrm{d}}$ & $6.73 \pm 0.09^{\mathrm{ab}}$ \\
\hline \multirow{5}{*}{$\mathrm{Lb}-1^{*}$} & 0 & $4.43 \pm 0.00^{\mathrm{b}}$ & $0.28 \pm 0.00^{r}$ & $4.92 \pm 0.10^{\mathrm{e}}$ & $5.78 \pm 0.03^{c}$ \\
\hline & 1 & $4.18 \pm 0.06^{\mathrm{d}}$ & $0.50 \pm 0.00^{\circ}$ & $5.73 \pm 0.10^{c}$ & $6.86 \pm 0.04^{\mathrm{a}}$ \\
\hline & 2 & $3.52 \pm 0.02^{\mathrm{g}}$ & $1.83 \pm 0.03^{\mathrm{k}}$ & $6.30 \pm 0.04^{\mathrm{a}}$ & $6.89 \pm 0.03^{\mathrm{a}}$ \\
\hline & 3 & $3.39 \pm 0.02^{\mathrm{h}}$ & $2.85 \pm 0.04^{\mathrm{h}}$ & $5.70 \pm 0.11^{c}$ & $6.75 \pm 0.04^{\mathrm{ab}}$ \\
\hline & 4 & $3.16 \pm 0.01^{1}$ & $5.86 \pm 0.02^{\mathrm{c}}$ & $5.69 \pm 0.15^{\mathrm{c}}$ & $6.80 \pm 0.04^{\mathrm{ab}}$ \\
\hline \multirow{5}{*}{$\mathrm{Lb}-2$} & 0 & $4.43 \pm 0.00^{\mathrm{b}}$ & $0.28 \pm 0.00^{r}$ & $4.16 \pm 0.01^{\mathrm{h}}$ & $5.78 \pm 0.03^{c}$ \\
\hline & 1 & $4.05 \pm 0.02^{\mathrm{e}}$ & $0.63 \pm 0.03^{\mathrm{m}}$ & $4.76 \pm 0.12^{\mathrm{f}}$ & $6.66 \pm 0.16^{\mathrm{ab}}$ \\
\hline & 2 & $3.41 \pm 0.03^{\mathrm{h}}$ & $2.16 \pm 0.02^{\mathrm{i}}$ & $6.10 \pm 0.02^{\mathrm{b}}$ & $6.76 \pm 0.11^{\mathrm{ab}}$ \\
\hline & 3 & $3.30 \pm 0.01^{\mathrm{j}}$ & $3.23 \pm 0.05^{\mathrm{g}}$ & $5.82 \pm 0.02^{\mathrm{c}}$ & $6.60 \pm 0.18^{b}$ \\
\hline & 4 & $3.05 \pm 0.04^{\mathrm{m}}$ & $5.46 \pm 0.04^{\mathrm{d}}$ & $5.75 \pm 0.15^{\mathrm{c}}$ & $6.65 \pm 0.06^{\mathrm{ab}}$ \\
\hline \multirow{5}{*}{$\mathrm{Lb}-3$} & 0 & $4.52 \pm 0.00^{\mathrm{a}}$ & $0.38 \pm 0.00^{\mathrm{p}}$ & $4.25 \pm 0.10^{\mathrm{g}}$ & $5.50 \pm 0.16^{\mathrm{d}}$ \\
\hline & 1 & $4.32 \pm 0.04^{c}$ & $0.50 \pm 0.03^{\circ}$ & $5.65 \pm 0.07^{c}$ & $6.61 \pm 0.03^{b}$ \\
\hline & 2 & $3.44 \pm 0.08^{\mathrm{gh}}$ & $1.88 \pm 0.05^{\mathrm{k}}$ & $6.24 \pm 0.05^{\mathrm{a}}$ & $6.61 \pm 0.13^{\mathrm{ab}}$ \\
\hline & 3 & $3.25 \pm 0.02^{\mathrm{k}}$ & $3.83 \pm 0.05^{\mathrm{f}}$ & $6.33 \pm 0.09^{a}$ & $6.88 \pm 0.10^{\mathrm{a}}$ \\
\hline & 4 & $3.01 \pm 0.01^{\mathrm{n}}$ & $7.01 \pm 0.01^{\mathrm{a}}$ & $6.38 \pm 0.04^{\mathrm{a}}$ & $6.72 \pm 0.10^{\mathrm{ab}}$ \\
\hline \multirow{5}{*}{$\mathrm{Lb}-4$} & 0 & $4.30 \pm 0.00^{c}$ & $0.25 \pm 0.00^{\mathrm{s}}$ & $4.35 \pm 0.10^{\mathrm{g}}$ & $5.66 \pm 0.02^{\mathrm{d}}$ \\
\hline & 1 & $4.06 \pm 0.03^{\mathrm{e}}$ & $0.56 \pm 0.02^{\mathrm{n}}$ & $5.25 \pm 0.14^{\mathrm{d}}$ & $6.68 \pm 0.13^{\mathrm{ab}}$ \\
\hline & 2 & $3.33 \pm 0.03^{i}$ & $2.06 \pm 0.04$ & $5.89 \pm 0.14^{\mathrm{bc}}$ & $6.78 \pm 0.08^{a}$ \\
\hline & 3 & $3.04 \pm 0.02^{\mathrm{m}}$ & $3.85 \pm 0.05^{f}$ & $6.11 \pm 0.06^{\mathrm{b}}$ & $6.91 \pm 0.12^{\mathrm{a}}$ \\
\hline & 4 & $3.03 \pm 0.01^{\mathrm{m}}$ & $6.01 \pm 0.03^{c}$ & $5.73 \pm 0.10^{c}$ & $6.68 \pm 0.06^{\mathrm{ab}}$ \\
\hline \multirow{5}{*}{$\mathrm{Lb}-5$} & 0 & $4.29 \pm 0.00^{c}$ & $0.32 \pm 0.00^{q}$ & $4.25 \pm 0.10^{\mathrm{g}}$ & $5.67 \pm 0.01^{\mathrm{d}}$ \\
\hline & 1 & $4.00 \pm 0.05^{\mathrm{e}}$ & $0.57 \pm 0.03^{n}$ & $5.60 \pm 0.11^{\mathrm{cd}}$ & $6.80 \pm 0.09^{\mathrm{ab}}$ \\
\hline & 2 & $3.34 \pm 0.01^{\mathrm{i}}$ & $2.14 \pm 0.02^{\mathrm{i}}$ & $6.17 \pm 0.08^{\mathrm{ab}}$ & $6.76 \pm 0.06^{\mathrm{ab}}$ \\
\hline & 3 & $3.14 \pm 0.06^{1}$ & $3.29 \pm 0.08^{\mathrm{g}}$ & $5.65 \pm 0.20^{\mathrm{cd}}$ & $6.67 \pm 0.07^{\mathrm{ab}}$ \\
\hline & 4 & $3.06 \pm 0.02^{\mathrm{m}}$ & $5.99 \pm 0.14^{c}$ & $5.69 \pm 0.12^{c}$ & $6.68 \pm 0.16^{\mathrm{ab}}$ \\
\hline
\end{tabular}

Different letters in superscript in columns indicate a significant difference at $p<0.05$ according to Tukey's HSD test. Lb-1-Lb-5: see Table 1.

two days as a consequence of the physiological activity of the tea fungus and production of organic acids (primarily acetic acid). After this period, the $\mathrm{pH}$ changed much slower despite the continued production of organic acids (Table 2), which could be explained by the buffer capacity of the fermentation broth. Namely, during the Kombucha fermentation, carbon dioxide is released as a result of metabolic activity of tea fungus yeasts. The water solution of $\mathrm{CO}_{2}$ dissociates and produces the amphiprotic hydrocarbonate anion $\left(\mathrm{HCO}_{3}^{-}\right)$, which easily reacts with hydrogen ions $\left(\mathrm{H}^{+}\right)$from the present organic acids, preventing further changes in $\mathrm{pH}$, thus contributing to a buffer character of the system [Cvetkovic et al., 2008]. This typical trend of $\mathrm{pH}$ changes during Kombucha fermentation was observed by other authors who used similar cultivation conditions [Blanc, 1996; Sreeramulu et al., 2000; Belloso-Morales \& Hernández-Sánchez, 2003]. Considering changes of basic chemical parameters during Kombucha fermentation, TA of fermentation broth should be used as 
a critical parameter instead of $\mathrm{pH}$ which determines the end of fermentation. Beverages with optimal consumption acidity $(\mathrm{TA}=4-4.5 \mathrm{~g} / \mathrm{L})$ in this paper were obtained in less than four days of fermentation.

The number of yeasts after inoculation was in the range from 5.50 to $5.78 \log \mathrm{cfu} / \mathrm{mL}$ (Table 3). In the following $24 \mathrm{~h}$, this number increased by up to one log unit. After that, the number of yeasts in the fermentation broth was uniform until the end of the process, for most of the samples (6.65$-6.80 \log$ units at the end), which has been confirmed by Tukey's HSD test (Table 3). The number of AAB at the start of fermentation was in the range from 4.16 to $4.92 \mathrm{log} \mathrm{cfu} / \mathrm{mL}$ (Table 3). The highest number of $\mathrm{AAB}$ at the end of fermentation was detected for Kombucha+Lb-3 (6.38 log cfu/mL) while Control Kombucha had the lowest AAB number (5.46 log cfu/ $\mathrm{mL}$ ). The number of $\mathrm{AAB}$ in fermentation broths reached the maximum after two days of fermentation for samples Kombucha+Lb-1 (6.30 cfu/mL), Kombucha+Lb-2 (6.10 cfu/ $\mathrm{mL})$, and Kombucha $+\mathrm{Lb}-5$ (6.17 cfu/mL); after three days for Control Kombucha (6.34 cfu/mL) and Kombucha+Lb-4 (6.11 cfu/mL); and after four days for Kombucha+Lb-3 $(6.38 \mathrm{cfu} / \mathrm{mL})$. Afterwards, the number of cells was reduced by $0.35-0.89 \log$ units until the end of fermentation. Numbers of yeasts and $\mathrm{AAB}$ in fermentation broths during tea fungus cultivation obtained in this study are comparable with the results reported by other authors. Teoh et al. [2004] found that the count of individual yeast species in fermentation broth was $4 \log$ units at the beginning of the process and reached the maximum of $7 \log$ units on the sixth day. During fermentation, the viable population of yeasts in Kombucha beverage followed a standard growth curve pattern, in which yeast grew exponentially for up to 8-10 days, dying off as nutrients depleted and $\mathrm{pH}$ decreased. Sreeramulu et al. [2000] studied the growth patterns of $\mathrm{AAB}$ in Kombucha fermentation broth and found that the count of $\mathrm{AAB}$ increased rapidly in 4 days of fermentation (from $4 \log$ units at the start of fermentation to more than $7 \log$ units after 4 days), declined drastically in 6 days of fermentation, and thereafter continued to decrease. The decreased count of AAB during tea fungus cultivation was probably caused by an acid shock. Production of acetic acid during tea fungus cultivation is directly related to the physiological activity and the count of $\mathrm{AAB}$ which enzymatically oxidize ethanol into acetic acid. However, the physiological activity of $\mathrm{AAB}$ during tea fungus cultivation cannot be considered separately from the role of yeasts in this consortium, it being the carbon source (glucose, fructose, and ethanol) needed by AAB. However, in all fermentations in this study, the number of yeasts and $\mathrm{AAB}$ during cultivation was not below $6 \log \mathrm{cfu} / \mathrm{mL}$, i.e. $5 \log \mathrm{cfu} / \mathrm{mL}$ (Table 3) which has provided efficient biotransformation of sweetened teas according to the TA results. These data on the number of yeasts and AAB are significant in the development of a concept of using isolated strains (pure culture) of yeasts and $\mathrm{AAB}$ as a starter culture for Kombucha fermentation.

The results of determinations of $\mathrm{pH}, \mathrm{TA}$, number of yeasts and $\mathrm{AAB}$ during Kombucha fermentation clearly demonstrated that the addition of wild strains of lactobacilli on the second day of fermentation affected the growth pattern, i.e. number of cells and physiological activity of tea fungus.
The cell number of wild Lactobacillus strains in fermentation broth determined after inoculation was between 7.13 (Lb-5) and $8.16 \log \mathrm{cfu} / \mathrm{mL}$ (Lb-1) (Table 2). This number was maintained until the end of the process only for strain Lb-1 (L. hilgardii). At the end of fermentation, cells of Lb-2 and Lb-3 were not detected in Kombucha beverages. At the same time, the initial number of strains Lb-4 and Lb-5 during fermentation decreased by $5 \log$ units. In the case of strains Lb-3, $\mathrm{Lb}-4$, and Lb-5 a significant reduction in their cell number was detected $24 \mathrm{~h}$ after inoculation (5.36, 3.93, and $4.66 \mathrm{log}$ unit, respectively), which confirms an assumption that Kombucha fermentation broth is not the most favorable environment for growth and proliferation of lactobacilli. Lee et al. [2016] have also examined the influence of different initial $\mathrm{pH}$ values at $30^{\circ} \mathrm{C}$ on the growth rate of $\mathrm{LAB}$. According to their results, all strains of $L$. plantarum did not grow at the initial $\mathrm{pH}$ of 2.0, while their slow growth was observed at the initial $\mathrm{pH}$ of 3.0. On the other hand, the species L. hilgardii seem to be more tolerant to lower $\mathrm{pH}$, as well as to high concentrations of ethanol and the environments with minor nutrient concentrations [Reis et al., 2018]. Cell number of Lactobacillus hilgardii from the moment of inoculation until the end of fermentation decreased only by $0.5 \log \mathrm{cfu} / \mathrm{mL}$. However, despite the largest number of viable cells during Kombucha fermentation, Lactobacillus hilgardii did not produce the largest quantity of lactic acids (Table 2).

The highest content of lactic acids $(247.6 \mathrm{mg} / \mathrm{L}$ and $95.5 \mathrm{mg} / \mathrm{L}$ of D- and L-lactic acid, respectively) at the end of the process was produced by strain Lb-4 (Lactobacillus plantarum from 40-day old cream) (Table 2) in spite of a significant reduction $(p<0.05)$ in the number of cells during fermentation (4.59 log units) (Table 3). In turn, the lowest content of $\mathrm{d}$ - and 1-lactic acids was produced by strains $\mathrm{Lb}-2$ ( 58.2 and $37.6 \mathrm{mg} / \mathrm{L}$, respectively) and $\mathrm{Lb}-3$ (11.1 and $53.6 \mathrm{mg} / \mathrm{L}$, respectively). The contents of $\mathrm{L}-$ and D-lactic acids in the Control Kombucha after 4 days of fermentation were 38.4 and $7.7 \mathrm{mg} / \mathrm{L}$, respectively. These results point to the fact that viability of lactobacilli does not necessarily have to influence the production of lactic acids. That is confirmed by Mathara et al. [2008] who reported about situations in which cell viability was not required for the physiological activity of LAB. In these cases, health beneficial effects have been linked to non-viable cells or to cell components, enzyme activities or fermentation products. However, wild strains of lactobacilli significantly affected the content and profile of lactic acid in fermentation broths and beverages (Table 2). In all fermentation broths, $24 \mathrm{~h}$ after inoculation with wild strains (the third day of cultivation), a significant $(p<0.05)$ increase was detected in the content of $\mathrm{L}$ - and $\mathrm{D}$ - lactic acid, compared with Control Kombucha. In the following $24 \mathrm{~h}$, the increase continued except for strain Lb-3 where d-lactic acid content was by $3.3 \mathrm{mg} / \mathrm{L}$ lower than on the previous day. Hence, while L-lactic acid predominates in the Control Kombucha, D-lactic acid prevailed in beverages obtained by the addition of wild strains. The content of D-lactic acid in the fermentation broth was higher than that of L-lactic acid for all wild strains with the exception of strain Lb-3 (Lactobacillus plantarum from 2-month old cheese). Malbaša et al. [2008] found that L-lactic acid was dominant in Kombucha and its final concentration af- 
TABLE 4. Value of $\mathrm{pH}$, titratable acidity (TA) (g/L), and number of cells (cfu/mL) of wild lactobacilli (LB-1, LB-4 and LB-5) during storage of Kombucha at $+4{ }^{\circ} \mathrm{C}$.

\begin{tabular}{l|c|c|c|c|c|c|c|c|c}
\hline \multirow{2}{*}{$\begin{array}{l}\text { Storage } \\
\text { duration } \\
\text { (days) }\end{array}$} & \multicolumn{3}{|c|}{ Lb-1 } & \multicolumn{3}{c|}{ Lb-4 } & \multicolumn{3}{c}{ Lb-5 } \\
\cline { 2 - 10 } & $\mathrm{pH}$ & $\mathrm{TA}$ & $\begin{array}{c}\text { Number } \\
\text { of cells }\end{array}$ & $\mathrm{pH}$ & $\mathrm{TA}$ & $\begin{array}{c}\text { Number } \\
\text { of cells }\end{array}$ & $\mathrm{pH}$ & TA & $\begin{array}{c}\text { Number } \\
\text { of cells }\end{array}$ \\
\hline 0 & $3.16 \pm 0.01^{\mathrm{b}}$ & $5.86 \pm 0.02^{\mathrm{a}}$ & $7.60 \pm 0.04^{\mathrm{a}}$ & $3.03 \pm 0.03^{\mathrm{b}}$ & $6.00 \pm 0.03^{\mathrm{b}}$ & $2.95 \pm 0.12$ & $3.06 \pm 0.02^{\mathrm{b}}$ & $6.04 \pm 0.16^{\mathrm{a}}$ & $1.90 \pm 0.01$ \\
2 & $3.16 \pm 0.01^{\mathrm{b}}$ & $5.19 \pm 0.10^{\mathrm{b}}$ & $7.55 \pm 0.03^{\mathrm{a}}$ & $3.04 \pm 0.01^{\mathrm{b}}$ & $6.09 \pm 0.09^{\mathrm{ab}}$ & $<1$ & $3.08 \pm 0.01^{\mathrm{b}}$ & $6.08 \pm 0.08^{\mathrm{a}}$ & $<1$ \\
4 & $3.16 \pm 0.02^{\mathrm{b}}$ & $5.18 \pm 0.11^{\mathrm{b}}$ & $7.37 \pm 0.05^{\mathrm{b}}$ & $3.03 \pm 0.03^{\mathrm{b}}$ & $6.08 \pm 0.05^{\mathrm{ab}}$ & $<1$ & $3.06 \pm 0.03^{\mathrm{b}}$ & $6.10 \pm 0.05^{\mathrm{a}}$ & $<1$ \\
6 & $3.25 \pm 0.03^{\mathrm{a}}$ & $5.31 \pm 0.03^{\mathrm{b}}$ & $7.15 \pm 0.03^{\mathrm{c}}$ & $3.15 \pm 0.04^{\mathrm{a}}$ & $6.15 \pm 0.01^{\mathrm{a}}$ & $<1$ & $3.15 \pm 0.02^{\mathrm{a}}$ & $6.15 \pm 0.10^{\mathrm{a}}$ & $<1$ \\
10 & $3.26 \pm 0.01^{\mathrm{a}}$ & $5.20 \pm 0.02^{\mathrm{b}}$ & $7.18 \pm 0.00^{\mathrm{c}}$ & $3.17 \pm 0.02^{\mathrm{a}}$ & $6.16 \pm 0.05^{\mathrm{a}}$ & $<1$ & $3.16 \pm 0.03^{\mathrm{a}}$ & $6.18 \pm 0.02^{\mathrm{a}}$ & $<1$ \\
\hline
\end{tabular}

Different letters in superscript in columns indicate a significant difference at $p<0.05$ according to Tukey's HSD test. Lb-1, Lb-4 and Lb-5: see Table 1 .

ter 14 days of fermentation on sucrose was $53 \mathrm{mg} / \mathrm{L}$. Belloso-Morales \& Hernández-Sánchez [2003] found that production of lactic acid in the black tea Kombucha reached a maximum $(1.15 \mathrm{~g} / \mathrm{L})$ after $96 \mathrm{~h}$ of cultivation. Generally, some differences in chemical parameters (such as lactic acid content), process duration, and cell counts in Kombucha beverages obtained in different studies are expected because of using inoculums (tea fungus culture) from different locations. The variations could be due to geographic, climatic, and cultural conditions as well as local species of wild yeasts and bacteria or, possibly, due to cross-contamination between cultures [Mayser et al., 1995; Teoh et al., 2004].

\section{Survival of wild strains of lactobacilli in Kombucha during storage}

After fermentation, the beverages containing living cells of wild strains of lactobacilli (Lb-1, Lb-4, and Lb-5) were bottled and stored at $+4^{\circ} \mathrm{C}$. Changes of $\mathrm{pH}$ and $\mathrm{TA}$, as well as the number of cells during storage for a period of 10 days are presented in Table 4. After 2 days of storage, cells of strains Lb-4 and Lb-5 were not detected in the bottled samples. During 10 days, the chemical characteristics $(\mathrm{pH}$ and TA) of each of three beverages changed statistically significantly $(p<0.05)$, except TA for beverage with strain Lb-5. At the same time, the number of Lactobacillus hilgardii (Lb-1) in the beverage decreased by $0.37 \log \mathrm{cfu} / \mathrm{mL}$. According to the Tukey's HSD test, statistically significant differences $(p<0.05)$ were noticed between mean numbers of lactobacilli during the storage period.

Strain Lb-1 (Lactobacillus hilgardii) showed an outstanding viability during both Kombucha fermentation (Table 2) and storage (Table 4). Resistance of Lactobacillus hilgardii to ecological conditions during fermentation and storage can be brought into correlation with the origin of this wild strain, which was the only one isolated from the sourdough. Sourdough is a medium which represents association of LAB and yeasts, and Lactobacillus hilgardii is a LAB species generally associated with sourdough fermentation [Corsetti \& Settanni, 2007]. It is well known that strains isolated from traditionally fermented food have enhanced metabolic activities in comparison to microorganisms that are used as industrial starter cultures [Klijn et al., 1995]. These include differences in growth rate and competitive growth behavior in mixed cul- tures, adaptation to a particular substrate or raw material, antimicrobial properties, and flavor, aroma, and quality attributes [Leroy \& De Vuyst, 2004].

\section{CONCLUSIONS}

Wild strains of Lactobacillus spp. have a potential to adapt to the environment such as Kombucha fermentation broth. Addition of these strains during Kombucha fermentation had no effect on the physiological activity of tea fungus, but contributed to a significant increase in lactic acids content in the beverage. The survival ability of wild lactobacilli, along with their ability to produce greater quantities of primarily L-lactic acid and possible probiotic properties, are key factors in the selection of strains which could be used in Kombucha fermentation. All the mentioned should result in producing a beverage of increased functional properties which is to be confirmed by further study.

\section{RESEARCH FUNDING AND ACKNOWLEDGEMENTS}

The authors declare that the research was conducted without funding.

\section{CONFLICT OF INTERESTS}

The authors declare that they have no conflict of interest.

\section{REFERENCES}

1. Aloulou, A., Hamden, K., Elloumi, D., Ali, M.B., Hargafi, K., Jaouadi, B., Ayadi, F., Elfeki, A., Ammar, E. (2012). Hypoglycemic and antilipidemic properties of kombucha tea in alloxan-induced diabetic rats. BMC Complementary and Alternative Medicine, 12(1), art. no. 63.

2. Banerjee, D., Hassarajani, S.A., Maity, B., Narayan, G., Bandyopadhyay, S.K., Chattopadhyay, S. (2010). Comparative healing property of kombucha tea and black tea against indomethacininduced gastric ulceration in mice: possible mechanism of action. Food \& Function, 1 (3), 284-293.

3. Belloso-Morales, G., Hernández-Sánchez, H. (2003). Manufacture of a beverage from cheese whey using a "tea fungus" fermentation. Revista Latinoamericana de Microbiologia , 45(1-2), 5-11. 
4. Blanc, P.J. (1996). Characterization of tea fungus metabolites. Biotechnology Letters, 18(2), 139-142.

5. Chakravorty, S., Bhattacharya, S., Chatzinotas, A., Chakraborty, W., Bhattacharya, D., Gachhui, R. (2016). Kombucha tea fermentation: Microbial and biochemical dynamics. International Journal of Food Microbiology, 220, 63-72.

6. Chen, C., Liu, B.Y. (2000). Changes in major components of tea fungus metabolites during prolonged fermentation. Journal of Applied Microbiology, 89(5), 834-839.

7. Chu, S.-C., Chen, C. (2006). Effects of origins and fermentation time on the antioxidant activities of Kombucha. Food Chemistry, 98(3), 502-507.

8. Corsetti, A., Settanni, L. (2007). Lactobacilli in sourdough fermentation. Food Research International, 40(5), 539-558.

9. Cvetković, D., Markov, S., Djurić, M., Savić, D., Velićanski, A. (2008). Specific interfacial area as a key variable in scaling-up Kombucha fermentation. Journal of Food Engineering, 85(3), 387-392.

10. Gao, M.G., Shimamura, T., Ishida, N., Takahashi, H. (2009). Fermentative lactic acid production with a metabolically engineered yeast immobilized in photo-crosslinkable resins. Biochemical Engineering Journal, 47(1-3), 66-70.

11. Greenwalt, C.J., Steinkraus, K.H., Ledford, R.A. (2000). Kombucha, the fermented tea: microbiology, composition, and claimed health effects. Journal of Food Protection, 63(7), 976-981.

12. Hiremath, U., Vaidehi, M., Mushtari, B. (2002). Effect of fermented tea on the blood sugar levels of NIDDM subjects. The Indian Practitioner, 55(7), 423-425.

13. Jacobson, J.L. (2006). Introduction to Wine Laboratory Practices and Procedures. Springer Science+Business Media, Inc, New York, pp. 275-277.

14. Jayabalan, R., Chen, P.N., Hsieh, Y.S., Prabhakaran, K., Pitchai, P., Marimuthu, S., Thangaraj, P., Swaminathan, K., Yun, S.E. (2011). Effect of solvent fractions of kombucha tea on viability and invasiveness of cancer cells - Characterization of dimethyl 2-(2-hydroxy-2-methoxypropylidine) malonate and vitexin. Indian Journal of Biotechnology, 10(1), 75-82.

15. Kandler, O., Weiss, N. (1984). Regular, Nonsporing Gram-Positive Rods. In Sneath, P.H.A., Mair, N.S., Sharpe, M.E., Holt, J.G. (Eds.), Bergey's Manual of Systematic Bacteriology, Williams and Wilkins, Baltimore, USA, pp. 1208-1235.

16. Kaufman, K. (1995). Kombucha Rediscovered, A Guide to the Medicinal Benefits of an Ancient Healing Tea. Alive Books, Canada, pp. $45-46$.

17. Klijn, N., Weerkamp, A.H. de Vos, W.M. (1995). Detection and characterization of lactose-utilizing Lactococcus spp. in natural ecosystems. Applied and Environmental Microbiology, 61 (2), 788-792.

18. Kurtzman, C.P., Robnett, C.J., Basehoar-Powers, E. (2001). Zigosaccharomyces komb-uchaensis, a new ascosporogeneous yeast from 'Kombucha tea'. FEMS Yeast Research, 1(2), 133-138.

19. Lee, K.W., Shim, J.M., Park, S.-K., Heo, H.-J., Kim, H.-J., Ham, K.-S., Kim, J.H. (2016). Isolation of lactic acid bacteria with probiotic potentials from kimchi, traditional Korean fermented vegetable. LWT - Food Science and Technology, 71, 130-137.

20. Leroy, F., De Vuyst, L. (2004). Lactic acid bacteria as functional starter cultures for the food fermentation industry. Trends in Food Science and Technology, 15(2), 67-78.
21. Lončar, E.S., Petrović, S.E., Malbaša, R.V., Verac, R.M. (2000). Biosynthesis of glucuronic acid by means of tea fungus. Food/ Nahrung, 44(2), 138-139.

22. Malbaša, R., Lončar, E., Kolarov, Lj. (2002). L-Lactic, L-ascorbic, total and volatile acids contents in dietetic kombucha beverage. Romanian Biotechnological Letters, 7(5), 889-894.

23. Malbaša, R., Lončar, E., Djurić, M. (2008). Comparison of the products of Kombucha fermentation on sucrose and molasses. Food Chemistry, 106(3), 1039-1045.

24. Marsh, A.J., O’Sullivan, O., Hill, C., Ross, R.P., Cotter, P.D. (2014). Sequence-based analysis of the bacterial and fungal compositions of multiple kombucha (tea fungus) samples. Food Microbiology, 38, 171-178.

25. Markov, S.L., Malbaša, R.V., Hauk, M.J., Cvetković, D.D. (2001). Investigation of tea fungus microbe associations. I. The yeasts. Acta Periodica Technologica, 32, 133-138.

26. Mathara, J.M., Schillinger, U., Guigas, C., Franz, C., Kutima, P.M., Mbugua, S.K., Shin, H.-K., Holzapfel, W.H. (2008). Functional characteristics of Lactobacillus spp. from traditional Maasai fermented milk products in Kenya. International Journal of Food Microbiology, 126(1-2), 57-64.

27. Mayser, P., Fromme, S., Leitzmann, C., Gruender, K. (1995). The yeast spectrum of tea fungus kombucha. Mycoses, 38(7-8), 289-295.

28. Nauth, K.R. (2006). Yogurt. In Hui, Y.H. (Ed.), Handbook of Food Science, Technology and Engineering, Taylor \& Francis Group, Boca Raton, London, New York, pp. 152-1-152-15.

29. Panesar, S.P., Kennedy, J.F., Gandhi, D.N., Bunko, K. (2007). Bioutilisation of whey for lactic acid production. Food Chemistry, 105(1), 1-14.

30. Ram, M.S., Anju, B., Pauline, T., Prasad, D., Kain, A.K., Mongia, S.S., Sharma, S.K., Singh, B., Singh, R., Ilavazhagan, G., Kumar, D., Selvamurthy, W. (2000). Effect of kombucha tea on chromate(VI)-induced oxidative stress in albino rats. Journal of Ethnopharmacology, 71(1-2), 235-240.

31. Reis, C.B., dos Santos, A.de O., Carvalho, B.F., Schwan, R.F., da Silva Ávila, C.L. (2018). Wild Lactobacillus hilgardii (CCMA 0170) strain modifies the fermentation profile and aerobic stability of corn silage. Journal of Applied Animal Research, 46(1), 632-638.

32. Reiss, J. (1994). Influence of different sugars on the metabolism of the tea fungus. Zeitschrift für Lebensmittel-Untersuchung undForschung, 198(3), 258-261.

33. Sievers, M., Lanini, C., Weber, A., Schuler-Schmid, U., Teuber, M. (1995). Microbiology and fermentation balance in kombucha beverage obtained from a tea fungus fermentation. Systematic and Applied Microbiology, 18(4), 590-594.

34. Sreeramulu, G., Zhu, Y., Knol, W. (2000). Kombucha fermentation and its antimicrobial activity. Journal of Agricultural and Food Chemistry, 48(6) 2589-2594.

35. Teoh, A.L., Heard, G., Cox, J. (2004). Yeast ecology of kombucha fermentation. International Journal of Food Microbiology, 95(2), 119-126.

36. Tripathi, M.K., Giri, S.K. (2014). Probiotic functional foods: Survival of probiotics during processing and storage. Journal of Functional Foods, 9, 225-241.

37. Velićanski, A. (2012). Characterization of functional lemon balm (Melissa officinalis L.) beverage obtained by physi- 
ological activity of tea fungus. PhD Thesis, Faculty of Technology, University of Novi Sad, Serbia, [http://nardus.mpn. gov.rs/bitstream/handle/123456789/9966/Disertacija17685. pdf? sequence $=1 \&$ isAllowed =y], pp. 75-108.

38. Yamada, Y., Hoshino, K., Ishikawa, T. (1997). The phylogeny of acetic acid bacteria based on the partial sequences of $16 \mathrm{~S}$ ribosomal RNA: the elevation of the subgenus Gluconoacetobacter to the generic level. Bioscience Biotechnology and Biochemistry, 61(8), 1244-1251.
39. Yang, Z.W., Ji, B.P., Zhou, F., Li, B., Luo, Y.C., Yang, L., Li, T. (2009). Hypocholesterolaemic and antioxidant effects of kombucha tea in high-cholesterol fed mice. Journal of the Science of Food and Agriculture, 89(1), 150-156.

Submitted: 25 February 2019. Revised: 4 June, 26 July, 2 August, 28 August, and 5 September 2019. Accepted: 11 September 2019. Published on-line: 2 October 2019. 
